\title{
Utilizing of 96\% Etanol Extract Activity Red Leaf (Syzygium myrtifolium Walp.) Maseration and Socletation Method as an Antidiarrhea at Male Mice
}

\author{
Moerfiah, Lusi Indriani, Raditya Pramayudha
}

\begin{abstract}
Diarrhea is still one of the most important public health problems because it is the third major contributor to child morbidity and mortality in Indonesia. One of the traditional medicines that can be used to treat diarrhea is red shoots. Red shoot leaves contain secondary metabolites such as alkaloids, flavonoids, chalcones, tannins, and terpenoids which can be used as antidiarrheals. The purpose of this study was to compare the antidiare effects between extracts of maceration and socletation of red shoot leaves and determine the effective dose of both extracts as antidiarrheal in male mice using the intestinal transit method. The treatment in this study consisted of the administration of ethanol extract of shoots of red shoots by maceration at a dose of $1.58 \mathrm{mg} / 20 \mathrm{~g} \mathrm{BW}$ (dose of MI), $4.75 \mathrm{mg}$ / $20 \mathrm{~g} \mathrm{BW}$ (dose of M.II), $6.33 \mathrm{mg} / 20 \mathrm{gBB}$ (Dosage M.III) and ethanol extract of shoots of red shoots by socletation at a dose of $1.67 \mathrm{mg} / 20 \mathrm{~g} \mathrm{BB}$ (SI dose), $5.04 \mathrm{mg} / 20 \mathrm{~g} \mathrm{BB}$ (Dosage S.II), $6.72 \mathrm{mg} / 20 \mathrm{~g} \mathrm{BB}$ (Dose S.III), Loperamid $\mathrm{HCl}$ as positive control, and 1\% CMC suspension as negative control. Observations were made by measuring the ratio of intestinal length traveled through the norit (marker) to the total gut length. The results showed that all dose treatments on maceration and socletation ethanol extracts had antidiareal activity. Different extraction methods give the same effect in giving antidiarrheal effects. Based on Duncan's advanced dose of $6.72 \mathrm{mg} / 20 \mathrm{~g} \mathrm{BW}$ of socletation results is an effective dose as antidiarrheal because it has an effect that is not significantly different than Loperamid $\mathbf{H C l}$.
\end{abstract}

Index Terms: Syzygium myrtifolium, antidiarrheal, maceration, socletation, redleaf

\section{INTRODUCTION}

According to the World Health Organization (WHO) and UNICEF, there are abouttwo billion cases of diarrheal disease worldwide every year, and 1.9 million children younger than 5 years of age perish from diarrhea each year, mostly in developing countries. This amounts to $18 \%$ of all the deaths of children under the age of five and means that more than 5000 children are dying every day as a result of diarrheal diseases. Of all child deaths from diarrhea, $78 \%$ occur in the African and South-EastAsian regions.Each child under 5 years of age experiences an average of three annual

Revised Manuscript Received on April 25, 2019.

Moerfiah, Department of Biology, Pakuan University, Bogor, Indonesia Lusi Indriani, Department of Pharmacy, Pakuan University, Bogor, Indonesia

Raditya Pramayudha, Department of Pharmacy, Pakuan University, Bogor, Indonesia episodes ofacute diarrhea. Globally in this age group, acute diarrhea is the second leading cause of death (after pneumonia), and both the incidence and the risk of mortality from diarrheal diseases are greatest among children in this age group, particularly during infancy - thereafter, rates decline incrementally. Other direct consequences of diarrhea in children include growth faltering, malnutrition, and impaired cognitive development in resource-limited countries [1].

Indonesia is known for its plant diversity which is beneficial to health, one of which is the Syzygium myrtifolium Walp plant, otherwise known as red shoot. Red shoot leaves contain secondary metabolites such as alkaloids, flavonoids, chalcones, tannins, and terpenoids [1]-[2]. The content of tannin in red shoots acts as adstringent. Adstrigen works as an antidiarrheal which contributes to shrinking the intestinal mucous membranes [3]. Flavonoids reduce intestinal motility, secretion of water and electrolytes [4] The Plant part wetr used in traditional medicine to cure various diseasea : dysentry, diabetes and gastric ulcer [5].

The purpose of this research is to know the comparison of ethanol extract activity of $96 \%$ red shoot as antidiarrheal by using maseration and sokletasi extraction method in male mice using transit intestinal method. Tests were performed on three different doses and compared to loperamide. This research is expected to improve the development of red shoot as a herbal medicine for diarrhea.

\section{METHODOLOGY}

\section{A. Simplisia preparation}

Four kilograms of red shoots were collected and cleaned from sticking dirt (sorting wet), washed with running water until clean, then drained. The next process leaves are separated from the stalk, and dried in an oven with a temperature of 50-60oC until dry. Dry simplicia is cleaned again from dirt that is not lost during washing (dry sorting). The next stage dried simplicia was milled to become a powder according to the degree of fineness of the simplicia of red shoot leaves (mesh 40), stored in a clean and tightly closed container ) [6].

\section{B. Extraction process}

1. Maceration

The sample was weighed $500 \mathrm{~g}$ and macerated with

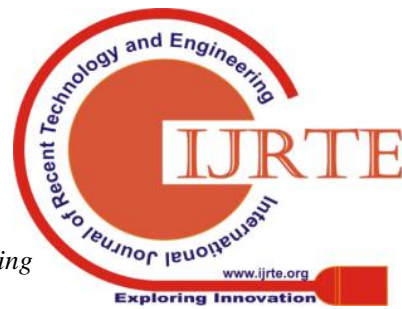




\section{Utilizing of 96\% Etanol Extract Activity Red Leaf (Syzygium myrtifolium Walp.) Maseration and Socletation Method as an Antidiarrhea at Male Mice}

$96 \%$ ethanol solvent as much as 6 liters with a ratio of 1:12 for 3 days protected from light, while occasionally stirring.

The sample was soaked using 2 L 96\% ethanol solvent for one day and stirred occasionally, then filtered using a batis cloth and the filtrate was poured. Maceration is repeated for 3 days. The three filtrate are combined then dried by using vaccum drier.

\section{Socletation}

One hundred grams of sample was wrapped in filter paper, tied with yarn, put into a soclet, then added with $1 \mathrm{~L}$ ethanol $96 \%$ solvent $(1: 10)$ into it. Socletation is carried out at a temperature of $70{ }^{\circ} \mathrm{C}$, until the droplets are colorless $(2$ repetitions). The liquid extract obtained is then dried using vaccum drier.

\section{Phytochemical screening}

\section{Alkaloid Test}

A $500 \mathrm{mg}$ extract was dissolved with $20 \mathrm{~mL}$ of ethanol then filtered. The filtrate is evaporated, then the residue is dissolved in $2 \mathrm{~mL}$ of methanol and used in the identification experiment. The filtrate was added with 2 drops of $2 \mathrm{~N}$ hydrochloric acid, then divided into three to use an identification test. Each solution plus Mayer, Bouchardat, and Dragendorff reagents. The sediment color formed is recorded. Positive results are shown by the formation of white deposits, blackish brown deposits and brick red deposits [7].

\section{Flavonoid test}

Five hundred milligrams of dried extract were dissolved using ethanol and then filtered. The test extract solution was evaporated to dryness, added 2-3 drops of ethanol, then add a little $\mathrm{Mg}$ powder and a few drops of $5 \mathrm{M} \mathrm{HCl}$ through the side of the tube. Red to red violet indicates the presence of flavonoids [7]. The formation of red to red-violet indicates the presence of flavonoids [7].

\section{Tanin Test}

$500 \mathrm{mg}$ of dried extract dissolved in ethanol. $1 \mathrm{~mL}$ extract solution was added to $2 \mathrm{~mL}$ of distilled water in a test tube, then added three drops of $1 \% \mathrm{FeCl} 3$ solution into the extract solution. If the blue-green color is formed, the extract contains tannin (cathechin tannin), whereas if it is blue-black, the extract contains tannin (gallic tannin). An extract of plant parts contains tannin if white precipitate is formed after being given a $1 \%$ gelatin solution containing $10 \%$ sodium chloride $(\mathrm{NaCl})[8]$.

\section{Saponin test}

A total of $100 \mathrm{mg}$ of extract dissolved in $2 \mathrm{~mL}$ of water was then put into a test tube, added $10 \mathrm{~mL}$ of hot water. After the solution is cooled, then shaked firmly for 10 seconds,

forming a steady foam for not less than 10 minutes, as high as $1 \mathrm{~cm}$ to $10 \mathrm{~cm}$. The froth does not disappear by adding 1 drop of $2 \mathrm{~N}$ hydrochloric acid [8].

\section{Animal Preparation Test}

Forty male mice were acclimatized for 1 (one) week in animal cages with the aim of adapting test animals to the new environment. Mice were randomly grouped into 8 (eight) groups, each of which had five male mice.

\section{Antidiarrheal Test}

Antidiarrheal test of young red leaf extract on experimental animals will be carried out with the following procedure:

a. Male mice fast for 18 hours, keep drinking given.

b. Then at time $\mathrm{t}=0$, given the treatment of the test substance $0.5 \mathrm{~mL} / 20 \mathrm{~g} \mathrm{BW}$ p.o mice with the following dose: Control (-): give treatment with CMC suspension $1 \% 0.5 \mathrm{~mL} / 20 \mathrm{~g} \mathrm{BW}$. The treatment was given with maceration (MI): (1.58 mg / 20g BW), M.II (4.75 mg / 20g BW), M.III: (6.33 mg / 20 g BW). Treatment of red shoot leaf extract resulting from socletation (S): S.I: (1.67 mg / 20 g BW), S.II: (5.04 mg / 20g BW), S.III :( $6.72 \mathrm{mg}$ / $20 \mathrm{~g} \mathrm{BW}$ ). Positive control (+): given loperamide suspension $0.02 \mathrm{mg} / 20 \mathrm{~g} \mathrm{BW}$.

c. After $\mathrm{t}=45$ minutes, all animals were given a norit 0.2 $\mathrm{mL} / 20 \mathrm{~g}$ BB suspension per oral.

d. At $\mathrm{t}=65$ minutes, all animals were killed by cervical dislocation. The intestine is removed and stretched carefully. The length of the intestine through which the norit marker starts from the pylorus to the end (black) is measured. Similarly the length of the entire intestine from the pylorus to the rectum of each animal. Then from each animal the normal ratio of the distance traveled by the marker to the length of the intestine is calculated.

e. If the test substance has antidiarrheal activity, the value of the ratio will be smaller when compared against control groups [9].

\section{Data analysis}

The statistical test used was ANOVA (Analysis of Variance) with factorial completely randomized design (CRD) at 95\% confidence level ( $\alpha 50.05$ ). Data processing results of the research were carried out with the SPSS 18.0 for Windows computer program.

\section{RESULTS AND DISCUSSION}

\section{A. Extraction Results}

\section{Maseration Method}

The extract obtained from maceration was $171.5 \mathrm{~g} / 500 \mathrm{~g}$ of simplicia, with a yield of $34.3 \%$. The size of the yield indicates the effectiveness of the extraction process. The effectiveness of the extraction process is influenced by the type of solvent used, the size of the simplicia particles, the extraction method, and the length of extraction [6].

\section{Organoleptic}

Organoleptic testing on extracts aimed at simple initial recognition was carried out as objectively as possible using the five senses by describing shape, color, Esmert, and taste [9]. 
Table 1: Results of Organoleptic Observations of Extracts

\begin{tabular}{llll}
\hline No & Organoleptic & \multicolumn{2}{c}{ Extraction } \\
\cline { 3 - 4 } & & Maceration & Socletation \\
\hline $\mathbf{1}$ & Form & Dry & Dry \\
$\mathbf{2}$ & Colour & Red brownish & Brown \\
$\mathbf{3}$ & Smell & Typical & Typical \\
$\mathbf{4}$ & Taste & Sepat & Sepat \\
\hline
\end{tabular}

\section{B. Phytochemical Screening Results}

Table 2: Results of Screening of Phytochemical Extracts

\begin{tabular}{|c|c|c|c|c|}
\hline \multirow{2}{*}{$\begin{array}{l}\text { Secondary } \\
\text { metabolite }\end{array}$} & \multirow[t]{2}{*}{ Reagent } & \multirow[t]{2}{*}{ Paramater } & \multicolumn{2}{|c|}{ Resuls observation } \\
\hline & & & Maceration & Sochletation \\
\hline \multirow{3}{*}{ Alkaloid } & Mayer & $\begin{array}{l}\text { White } \\
\text { Sediment }\end{array}$ & + & ++ \\
\hline & Boucherdat & $\begin{array}{l}\text { Blackish } \\
\text { brown } \\
\text { sediment }\end{array}$ & + & + \\
\hline & Dragendorfff & $\begin{array}{l}\text { Brick red } \\
\text { sediment }\end{array}$ & + & + \\
\hline Flavonoid & $\mathrm{Mg}+\mathrm{HCl}$ & Yellow red & + & + \\
\hline \multirow[t]{2}{*}{ Saponin } & $\begin{array}{l}\text { Hot water + } \\
\mathrm{HCl}\end{array}$ & $\begin{array}{l}\text { Foam } \\
\text { stable }\end{array}$ & + & + \\
\hline & $+\mathrm{FeCl}_{3} 1 \%$ & $\begin{array}{l}\text { Green } \\
\text { black }\end{array}$ & + & ++ \\
\hline \multirow[t]{2}{*}{ Tanin } & + gelatin & $\begin{array}{l}\text { White } \\
\text { sediment }\end{array}$ & + & ++ \\
\hline & $\begin{array}{l}+ \\
\text { NaCl-gelatin }\end{array}$ & $\begin{array}{l}\text { White } \\
\text { sediment }\end{array}$ & + & ++ \\
\hline
\end{tabular}

Description:

$++=$ positive contains more compounds

$+=$ positive to contain compounds

- = negative contains compounds

\section{Antidiarrheal test}

Research This antidiarrheal activity test, using the intestinal transit method. The purpose of this study was to determine the antidiare activity of ethanol extract $96 \%$ of red shoot leaves Syzygium myrtifolium Walp with maceration and socletation methods in various doses against male mice.

The principle of the intestinal transit method is to compare the length of the intestine the marker passes to the overall intestinal length. The marker used in this study is a $5 \%$ norit suspension in $1 \% \mathrm{CMC}$. Norit is a compound that is adsorbent and cannot be digested. Norit will color the intestine so that it is easy to measure. Comparison or ratio of the distance of the intestine through norit to the overall intestinal length of the extract was measured, then analyzed by variance analysis to find out the differences of each treatment.

The positive control used in the study was Loperamid $\mathrm{HCl}$ as a comparison of the antidiarrheal effect on ethanol extract of red shoot leaves. Selection of Loperamid $\mathrm{HCl}$ as a positive control because Loperamid $\mathrm{HCl}$ is an effective drug as an antidiarrheal. Loperamide $\mathrm{HCl}$ and its analogues are peristalsis suppressants, thus giving more time for absorption of water and electrolytes by the intestinal mucosa. This drug is able to normalize the balance of absorption and secretion from mucosal cells, which is to restore cells that are in a hypersecretion state to a normal absorption state [3].

Before treatment, mice were fasted for 18 hours before the study but drinking was still given. This is because food in the intestine will affect the speed of peristalsis

Table 3: Antidiare activity of red shoot leaves ethanol extract against intestinal length ratio

\begin{tabular}{llc}
\hline Treatment group & \multicolumn{2}{c}{ Average ofi ntestinal length ratio } \\
\cline { 2 - 3 } & \multicolumn{1}{c}{ Maceration } & Sochletation \\
\hline Negative controle & $58,36 \pm 4,31^{\mathrm{e}}$ & $58,36 \pm 4,31^{\mathrm{e}}$ \\
Positive controle & $26,46 \pm 3,99^{\mathrm{a}}$ & $26,46 \pm 3,99^{\mathrm{a}}$ \\
$\mathbf{1}^{\text {st }}$ dose & $44,60 \pm 5,09^{\mathrm{d}}$ & $46,96 \pm 3,62^{\mathrm{d}}$ \\
$\mathbf{2}^{\text {nd }}$ dose & $38,32 \pm 5,44^{\mathrm{c}}$ & $34,54 \pm 2,36^{\mathrm{bc}}$ \\
$\mathbf{3}^{\text {rd }}$ dose & $334,73 \pm 4,07^{\mathrm{bc}}$ & $30,22 \pm 4,60^{\mathrm{ab}}$ \\
\hline
\end{tabular}

Description: Values followed by different superscripts in the same column show significant differences

The data obtained were statistically analyzed using the SPSS 18.0 application to see the difference test (Anova) then continued with Duncan's test. Anova test results of antidhiareal activity of red shoot leaf extract from maceration (Table 3, obtained very significant results ( $\mathrm{P}<0.05$ Anova test results of antidhiareal activity of red shoots from maceration (Table 3) showed very significant results ( $\mathrm{P}$ $<0.05)$, meaning that the treatment of doses showed a very significant effect on the ratio of length of intestine passed by norit to male mice. The decrease in intestinal length ratio traversed by norit showed a slowing of intestinal peristaltic movement. Duncan's test on antidiareal activity testing of maceration extract showed that the treatment of dosage variation was very significantly different from the negative control of slowing intestinal peristaltic motion. Duncan's test results on extracts of socletation (Table 3 ) show that giving the treatment of red leaf extract in various doses gives a significantly different effect on the ratio of intestine through norit marker compared to negative control. The treatment of red shoot leaf extract by socletation at a dose of $6.72 \mathrm{mg} / 20$ $\mathrm{g} \mathrm{BW}$ has the effect of norit intestinal transit ratio which is not significantly different than positive control.

Statistical test of differences in extraction method showed no significant difference between maceration extraction method and socletation. The difference in extraction method gives the effect of norit intestinal transit ratio, which is not significantly different. This is supported by the results of the T-test which also obtained results were not significantly different between the two extraction methods ( $\mathrm{P}>0.05)$. This means that the difference in extraction methods does not have a different effect on antidiarrheal effects.

The method of socletation is extraction using solvents that are always new, generally carried out with special tools so that continuous extraction occurs with a relatively constant amount of solvent with the back cooling [9]. The extraction process is affected by temperature, particle size, solvent type, extraction time, and extraction method. Socletation gives higher extract quality because in this way the expected heating is used improve solubility of extracts [10]. This also happens because socletations run perfectly which are characterized by cycles that are colorless or clear.

In addition to producing good extracts, the method of socletation can also attract active substances that are better than the maceration method. This is evidenced by the results of phytochemical screening, namely the results

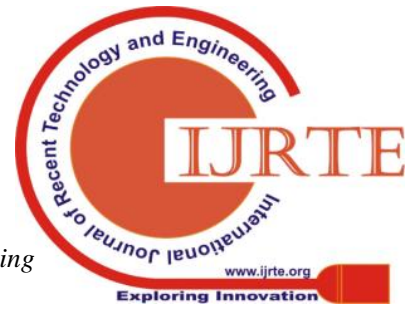




\section{Utilizing of 96\% Etanol Extract Activity Red Leaf (Syzygium myrtifolium Walp.) Maseration and Socletation Method as an Antidiarrhea at Male Mice}

of tannin testing. In tannin testing with gelatin solution, the results of socletation produced more white deposits than the results of maceration. Likewise with the NaCl-Gelatin solution (1:1) the white precipitate produced in the extract of the socletation was more than the maceration results.

The content of tannin and flavonoid compounds in extracts of red shoots of Syzygium myrtifolium Walp are suspected to have antidiareal activity. Tanin acts as an antidiarrheal which works as an adstringentia mechanism, able to shrink the mucous membrane of the intestine and strengthen the intestinal wall sothe possibility of blocking the absorption of bacteria and toxins while reducing fluid expenditure [11].

Flavonoids have the ability to inhibit intestinal motility, secretion of water and electrolytes [4] $96 \%$ extract of red shoots is also able to inhibit the growth of E. coli bacteria which is one of the diarrhea-causing bacteria [2].

\section{CONCLUSION}

Ethanol extract $96 \%$ of red shoot leaves has a pharmacological effect as an antidhiare, proven to have a very significant effect on the decrease in the transit ratio of norit in male mice. Maseration and socletation extraction methods have the same effect as antidiarrheal. The dose of $6.72 \mathrm{mg} / 20 \mathrm{~g} \mathrm{BB}$ (dose S.III) results of the socletation is an effective dose of ethanol extract of red shoot leaves as an antidiarrheal in male mice because it has an effect almost equivalent to Loperamid $\mathrm{HCl}$.

\section{REFERENCES}

1. A. F. Aisha, Z. Ismail, K. M. Abu-Salah, J. M. Siddiqui, G. Ghafar and A. M. S. A. Majid. "Syzygium campanulatum korth methanolic extract inhibits angiogenesis and tumor growth in nude mice." $B M C$ complementary and alternative medicine, vol. 13 , no. 1 , art. no. 168 , 2013.

2. N. A. Haryati and C. Saleh. "Uji Toksisitas Dan Aktivitas Antibakteri Ekstrak Daun Merah Tanaman Pucuk Merah (Syzygium Myrtifolium Walp.) Terhadap Bakteri Staphylococcus Aureus Dan Escherichia Coli." Jurnal Kimia Mulawarman, vol. 13, no. 1, pp. 35-40, 2016.

3. T. H. Tjay and K. Rahardja. Obat-obat Penting Khasiat, Penggunaan, dan Efek-Efek Sampingnya, Jakarta: PT. Elex Media Komputindo, 2002.

4. F. A. Fajrin. "Aktivitas Antidiare Ekstrak Etanol Daun Seledri (Apium Graveolens L) Pada Mencit Jantan." Pharmacy: Jurnal Farmasi Indonesia, vol. 9, no. 1, pp. 1-8, 2012.

5. L. Bakshu, "Ethnomedicobotanical and phytochemical evaluation of certain rare, endemic and endangered medicinal plants from Eastern Ghats. Andhra Pradesh, India," Ph.D dissertation, Sri Krishnadevaraya University, Anantapur, 2002.

6. Departemen Kesehatan Republik Indonesia. Materia Medika Indonesia, Jilid VI. Direktorat Jenderal Pengawasan Obat dan Makanan, Jakarta. 2000.

7. E. Hanani, Analisis Fitokimia. Jakarta: Buku Kedokteran EGC, 2015.

8. A. C. Kumoro, Teknologi Ekstrak Senyawa Bahan Aktif dari Tanaman Obat. Yogyakarta: Plantaxia, 2015.

9. Kelompok Kerja Ilmiah. Pedoman Pengujian dan Pengembangan Fitofarmaka: Penapisan Farmakologi, Pengujian Fitokimia dan Pengujia $n$ Klinik. Jakarta: Yayasan Pengembangan Obat Bahan Alam Phyto Medica, 1993.

10. D. Grigonis, P.R. Venskutonis, B. Sivik, M. Sandahl and C. S. Eskilsson. "Comparison of different extraction techniques for isolation of antioxidants from sweet grass (Hierochloe odorata)." The Journal of Supercritical Fluids, vol. 33, no. 3, pp. 223-233, 2005.

11. L. P. Suherman, F. Hermanto and M. L. Pramukti. "Efek antidiare ekstrak etanol Daun Mindi (Melia azedarach Linn) pada mencit swiss webster jantan.” Kartika: Jurnal Ilmiah Farmasi, vol. 1, no. 1, pp. 38-44, 2013. 